\title{
Las imágenes del Vuelo Americano muestran la transformación del territorio andaluz en el último medio siglo
}

Las consejerías de Obras Públicas y Vivienda y de Medio Ambiente han culminado el proceso de recuperación y posterior edición del material fotográfico aéreo captado sobre el territorio español por la United States Air Force (USAF) entre los años 1956 y 1957. Transformado dicho material en ortofotografía a partir de la digitalización de los negativos originales, constituye un documento de valor excepcional para investigadores del territorio y público en general.

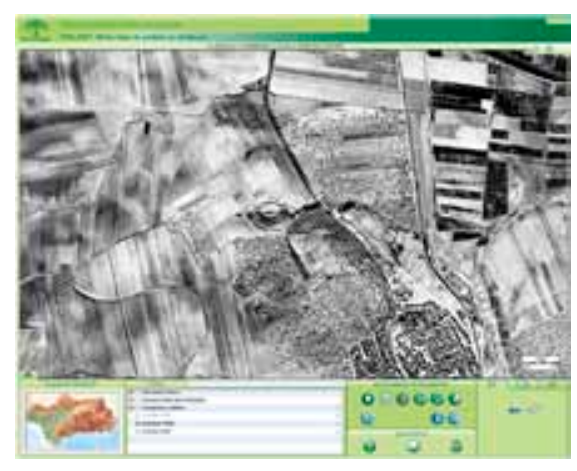

Ortofotografía del yacimiento arqueológico de Itálica captada en el Vuelo Americano.

Fuente: Junta de Andalucía

En el contexto de la Guerra Fría, a comienzos de la década de los cincuenta, el Ejército de los Estados Unidos de Norteamérica valoró la importancia geoestratégica de la Península Ibérica y fijó entre sus objetivos clave el establecimiento de relaciones con España. Fruto de este acercamiento se producen los Ilamados Acuerdos de Amistad Hispano-Americanos, rubricados por ambos gobiernos en el año 1953, acuerdos que permiten a los norteamericanos incluir a España en su área de influencia y por los que el régimen del General Franco obtiene una importante ayuda económica y militar $y$, sobre todo, reconocimiento internacional. Uno de los resultados de estos acuerdos es el conocido como Vuelo Americano, un vuelo fotogramétrico, orientado a la producción cartográfica, realizado en blanco y negro por la Fuerza Aérea de los Estados Unidos (USAF) entre los años 1956 y 1957
El Vuelo Americano permitió entonces obtener una imagen fija de gran calidad, que facilitó, por primera vez, la posterior cobertura cartográfica de todo el país a escala 1: 50.000 de forma ágil y económica, por lo que supuso uno de los principales hitos en la modernización de la cartografía española. El uso del vuelo, debido a la cantidad de áreas censuradas, quedó restringido a los ámbitos institucionales.

El proceso de recuperación de este material ha sido largo y complejo. Tras obtener el Instituto de Cartografía de Andalucía (ICA) de la Consejería de Obras Públicas y Vivienda una copia de los negativos originales, depositados en el Centro Car-

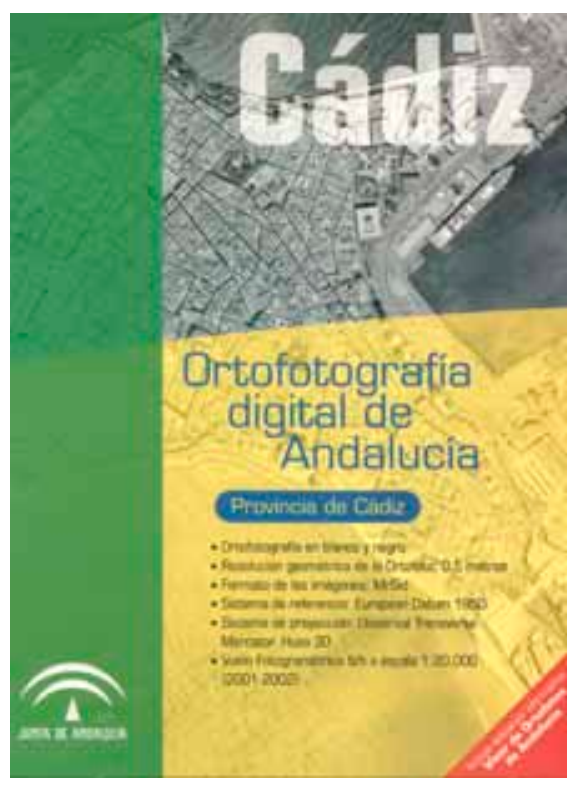

Imagen de portada de uno de los 8 DVDs editados tográfico y Fotográfico del Ejército del Aire, la Consejeria de Medio Ambiente ha digitalizado estos negativos. Un posterior convenio firmado con el citado Centro Cartográfico permite la difusión de este material documental de valor excepcional para historiadores, arqueólogos, estudiosos del paisaje y público interesado en general. La singularidad de estas imágenes reside en que muestran un territorio apenas transformado, donde pueden observarse aún los aprovechamientos agrarios y forestales no mecanizados, debido a que son anteriores al Plan de Estabilización que modernizó el país.

El proyecto de recuperación de las imágenes del Vuelo Americano ha culminado en la publicación Ortografía digital histórica de Andalucía 1956-2007. Medio siglo de cambios en Andalucía en 8 DVDs, uno por cada provincia andaluza. Editada la obra conjuntamente por las dos consejerias, muestra las ortos, que están realizadas a escala 1: 33.000 a modo de mosaico continuo. Éstas se acompañan asimismo de una ortofotografía elaborada por el ICA en 2007 y de una aplicación que permite la comparación de la captura de los años cincuenta con la imagen aérea actual y, por tanto, la evaluación de las transformaciones del territorio andaluz en los últimos cincuenta años. Asimismo, las imágenes aparecen georreferenciadas con información complementaria sobre carreteras, núcleos de población, relieve del territorio, hidrografía, así como datos referentes a los términos municipales, lo que la convierte en una herramienta de gran utilidad para la investigación y los usuarios profesionales.

La publicación está también disponible en las webs y de las consejerias de Obras Públicas y Vivienda y de Medio Ambiente.

Antonio Fajardo

Servicio de Difusión

Instituto de Cartografía de Andalucia 